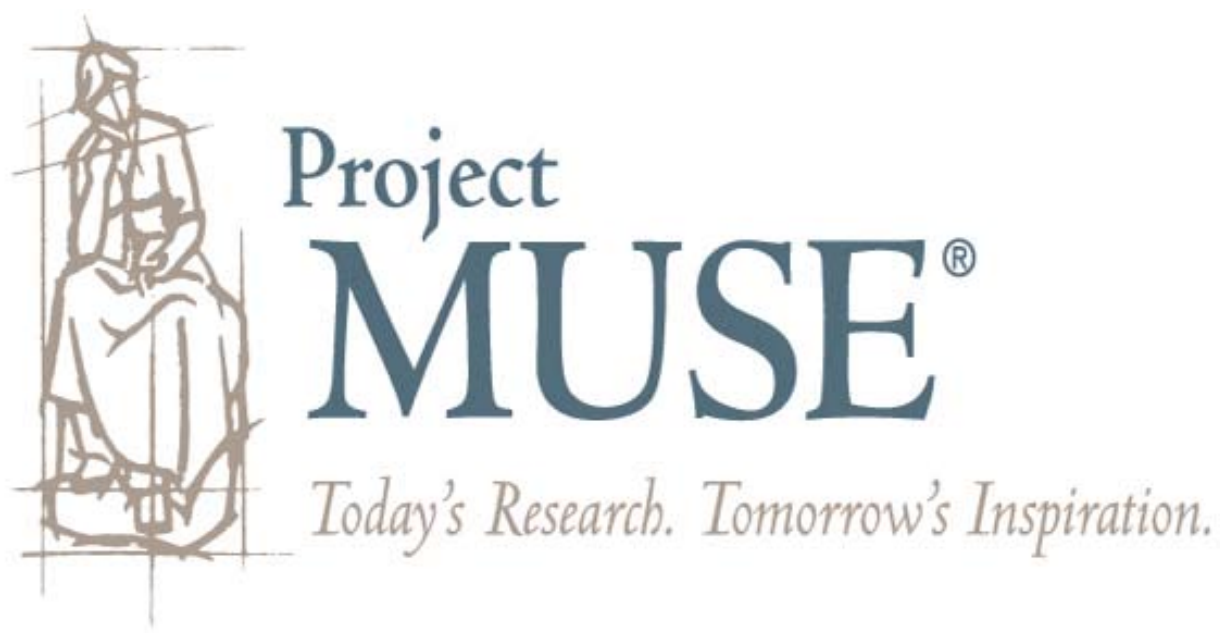


Moira Smith

\title{
Humor, Unlaughter, and Boundary Maintenance
}

\begin{abstract}
Some joke performances are meant to elicit differential responses-laughter from some, and unlaughter from salient others - and so serve as powerful methods for heightening group boundaries. This article illustrates this thesis by analyzing audience responses to practical jokes and to the Muhammad cartoons that aroused worldwide controversy in 2006. To further make this case, I will delineate a theory of the audience for humor. Such a theory has heretofore been largely missing from both folklore and humor scholarship; instead, the lion's share of scholarly attention has gone to the performers, with the audience's role taken for granted. In boundary-heightening humor, the audience response is the subject of special attention, and it is interpreted in terms of contemporary notions about the importance of having a sense of humor and especially of being able to laugh at oneself.
\end{abstract}

Jokes and humor have attracted a fair amount of serious attention by folklorists, but outside of our field these topics are often easily dismissed as trivial and insignificant. However, in January and February of 2006, a series of cartoons published in a Danish newspaper sparked an enormous international furor that was anything but inconsequential. Diplomats were recalled and Danish products were boycotted in several countries. Thousands demonstrated in protests around the globe, some of which turned into violent riots that left buildings burned and protestors dead and injured. If ever we needed proof that humor is not a trivial matter, this grim series of events was it.

The subject of this international incident was a series of political cartoons that depicted the prophet Muhammad. Among the images seen as particularly offensive were a villainous-looking Prophet with a turban that merged with a bomb and another depicting the Prophet telling a line of charred suicide bombers at the gates of Paradise that they had run out of virgins. Jyllands-Posten, Denmark's largest daily newspaper, had invited cartoonists to submit works featuring the Prophet, although they knew that to fundamentalist Muslims, any such images would be offensive, even blasphemous. The paper issued the invitation in response to a Danish author's complaint that he could not find anyone to illustrate his children's book about Islam because all the potential collaborators feared a negative Muslim response. When the resulting cartoons were published in September 2005, Muslim leaders in Denmark

Morra SMith is Librarian for Folklore at Indiana University, Bloomington

Journal of American Folklore 122(484):148-171

Copyright $\odot 2009$ by the Board of Trustees of the University of Illinois 
protested, and there were peaceful demonstrations in Copenhagen demanding an apology (Hamilton 2006; Rose 2006a, 2006b; copies of the cartoons in question can be found in Spiegelman 2006). ${ }^{1}$

Thus far, not much had happened that would have attracted attention outside of Denmark; it was just another case of controversial humor in the public arena. However, two further developments served to propel these cartoons forcefully onto the world stage. First, a delegation of Danish Muslims took copies of the cartoons and other anti-Muslim caricatures to leaders in Egypt, Syria, and other Muslim countries. Second, a Norwegian newspaper republished the cartoons in January 2006. Thereafter, the stage was set for an international diplomatic and political confrontation that extended around the world and unleashed a storm of enflamed rhetoric.

In the resulting international debate, the key issues were often understood to be a face-off between competing rights: on one hand, freedom of expression; on the other, the expectation of tolerance and respect for religious sensibilities. Both positions were elevated to dizzying heights of importance by being placed in a context of a confrontation between the secular West and the Muslim East. ${ }^{2}$ Once the protests began, the cartoons' status was irrevocably changed from a public humor performance into a high-stakes game of a "clash of civilizations." Thereafter, the images meant something quite different from what they had at first. Depending on which side the observer was on, they signified either freedom of speech, secular humanism, and the virtues of Western democracy, or blasphemy, Islamophobia, religious and ethnic intolerance, insensitivity, and the evils of Western democracy and secularism. High stakes, indeed.

Alongside this high-flown rhetoric, some of the protestors and defenders focused on the fact that the images at issue were cartoons, a genre that today is usually considered a form of humor. Flemming Rose, the culture editor of the Danish newspaper that started the affair, set his decision to run the cartoons squarely in the context of the Danish "tradition of satire and humour" ("Danish Editor Defends Mohammed Cartoons to BBC" 2006), and in the West many pundits, journalists, and ordinary writers of letters to the editor criticized the rioters for lacking a sense of humor. ${ }^{3}$ Many Westerners were baffled by what they saw as the extreme disjunction in scale between the tiny offending object and the massive response. The angry and violent nature of the protests was condemned even more forcefully because the precipitator of the violence seemed so insignificant-mere cartoons. This line of argument focusing on the cartoons' status as a species of humor was popular, even though a case can be made that political cartoons and caricatures often have more to do with social critique and satire than with amusement: the biting political satire of Thomas Nast's cartoons are a good case in point (Spiegelman 2006).

Western news stories endlessly repeated the explanation that, to Muslims, any image of the Prophet is blasphemous. ${ }^{4}$ We can only speculate about what motivated some protestors to boycott Danish goods, burn effigies, or storm embassies, but it seems reasonable to suppose that the responses and rhetoric would have been different if the images at issue had been portraits instead of caricatures. Where a straight portrait might have been protested as idolatrous, a cartoon is even more disrespect- 
ful, because of its critical thrust and because its association with humor, however tenuous, inevitably ridicules and trivializes the subject (see Oring 1995:169).

Most of the people who protested the cartoons did so without ever having seen the offending images themselves. The few editors in the Muslim world who republished the cartoons were swiftly sanctioned (Slackman and Fattah 2006). Furthermore, when the envoys from the Danish Muslim community traveled abroad seeking support for their protest of the Jyllands-Posten cartoons, the portfolio of examples that they took along included a number of images besides those that the Danish paper had published. The additions were much more unambiguously insulting depictions, including a cartoon showing a Muslim man kneeling in prayer being raped by a dog (an unclean animal in Muslim thought) and a photograph of a man wearing a pig mask who was alleged to be a representation of the Prophet (Spiegel 2006). Most of the defenders in the debate seemed unaware of the existence of the latter images, creating a situation where the different sides were unwittingly arguing about the meaning of different things. At the very least, protestors were responding to what they saw as a gratuitous insult, whereas defenders frequently based their argument on the assumption that the contested images were intended as humorous.

The topic of this article is the part of the controversy that focused on humor. Specifically, those who talked about the role of humor in this affair drew upon widespread, popular ideas about the significance of the reception of humor, according to which the ways that individuals respond to humor provide accurate, infallible indicators of their personality and character. In addition to addressing issues of free speech, the cartoons arose from and represented another core value of the contemporary Western world, a value that I call the importance of being humorous. The contemporary importance that is placed on the sense of humor, I argue, fuels strategic uses of humor performances to provoke humorless responses and, in so doing, to heighten social boundaries. In all of the above, the focus of attention is on audiences rather than performers. The humorous texts themselves may be of less interest than their reception and the interpretation of the audience response. Humor is widely recognized as a builder of social solidarity, but I wish to focus on the fact that when the laughter is not shared, it constructs exclusion as much as inclusion.

\section{A Theory of the Humor Audience}

The international furor over these cartoons was a spectacular case of performance failure-that is, if we assume that the goal of a performance of humorous genres is to elicit laughter. As the world saw, a lot of people were not laughing at these jokes; on the contrary, they refused to agree with the claim that they were jokes at all.

Michael Billig (2005) has coined the term unlaughter to characterize situations like this. Unlaughter is much more than the mere absence of laughter; most of our daily doings are accompanied by the absence of laughter, and this absence is not remarkable. Unlaughter, in contrast, is "a display of not laughing when laughter might otherwise be expected, hoped for or demanded" (192)—for example, after the performance of a joke or the reception of a cartoon. As such, he suggests, unlaughter is socially powerful and very significant whenever it occurs. And it happens often (see, 
for example, Lewis 2006a:109-54; Saltzman and Smith 1995). Further, as the Danish cartoon controversy amply shows, the consequences of unlaughter can be anything but trivial. Yet with only a few exceptions, those who study humorous genres have rarely paid attention to unlaughter. I argue that unlaughter is not always just a regrettable accident but may be used deliberately by both joke instigators and members of joke audiences to highlight the supposed differences between them and so heighten exclusionary social boundaries.

Any analysis of unlaughter requires a focus on the reception of humorous genres and on the role of the audience in performance. Generally, however, studies of humor performance do not look closely at reception, and those that do talk about the reception of humor rarely consider specific performances. Many folkloristic studies of jokes are text-centered, with attention given mostly to content analysis, interpretation, and speculation about what the joke texts tell us about the motivations of the people who repeat them or about the prevalent anxieties of the day (Barrick 1970; Brunvand 1970; Dundes 1987; Ellis 1991; Smyth 1986). ${ }^{5}$ Since many of these studies examine jokes that may be considered offensive-notably disaster jokes, "gross jokes" (Bronner 1985), and ethnic jokes - the possibility of unlaughter arises, even in the absence of accounts of specific performances; but in the discussions of these controversial jokes, the implied question has been only, should they be funny. The question of whether or not they are funny-when and to whom-is usually left untouched. In other words, the funniness of jokes and similar genres is simply assumed. Indeed, jokes are sometimes defined as humorous texts, rendering out of bounds the question of whether a particular joke is humorous or not.

There have also been numerous folkloristic studies of jokes and other humorous genres that are influenced by performance theory and so examine specific instances of joke telling in context. Some folklorists have examined the way that the jokes told on particular occasions relate to the immediate context of the performance-for example, serving to comment upon topics in the preceding conversation (Kirshenblatt-Gimblett 1975; Oring 2003:85-96). Others have considered the ways that humor operates in group dynamics (Fine 1984; Fine and De Soucey 2005) or how performers use jokes strategically to achieve particular social goals (Johnson 1973; Walle 1976). Still others have focused on the performer, analyzing personal performance styles and preferences (Bauman 1986; Bendix 1984; Bronner 1984) or the relationship between a joke teller's personality and repertoire (Oring 1992:94-111). However, there has been little or no study of unlaughter by performance-centered scholars of humor, first because of a tendency to prefer successful performances and second because the lion's share of attention tends to go to performers rather than to audiences. It is not surprising that most folklore research on performance has centered either on the texts or on the performers, since by definition performance calls attention to itself and, by extension, its performers, whom Henry Glassie (2006) calls the "stars" and who are also greedy for attention and applause. While audiences are considered essential to performance, their role is—with a few exceptions, notably Dan Ben-Amos (1972) — usually taken for granted.

There has been a similar neglect of unlaughter in humor studies generally. Perhaps the most influential approach to humor at present is that represented by the seman- 
tic theories of Victor Raskin (1985) and Salvatore Attardo (2001). These theories seek the source of humorousness in the structure of jokes and longer comic texts, and they explicitly eschew any interest in specific performances in favor of proposing a theory of speakers' competence at producing and interpreting humor. Attardo explains, "When interested in the structure of a humorous text (mainly, what makes it funny) one can and must abstract away from the reception of said text by any given audience. Their reactions are essentially irrelevant, since what is being investigated is an abstract 'ideal' reader's analysis of the text" (2001:30). This approach renders jokes and joking situations noncultural and nonsocial and makes questions of audience reception irrelevant. When it comes to humor disputes such as the Muhammad cartoon controversy, however, the issue of the reception of humor must take center stage.

Although humor scholarship still awaits the development of an adequate theory of the audience (Attardo 2003:1289), the prototypical elements of such a theory may be found in sociological and especially in sociolinguistic studies of humor (e.g., Carrell 1997; Fine 1984; Hay 2001; Norrick 1993). Some folklorists have also resisted the usual trend of taking the audience for granted, for example by asking people who laugh at particular jokes to explain what they thought was funny (Mitchell 1977; Thomas 1997). In addition, a few folklorists and humor scholars have studied the audience and public responses to controversial jokes (Lockyer and Pickering 2001; Michael 1995; Smith 1995). Together, these studies provide insights that may be formulated into a foundation for a comprehensive theory of the audience for humor.

The audience is vital to any performance, but it is especially so when the performance is a humorous one. A joke requires, even demands, a response (Fine 1984). This is because any humorous performance represents a unilateral switch from what Michael Mulkay has referred to as the "serious mode of discourse" to the "humorous" one (1988:220-2). Humorous and serious modes of discourse represent incompatible approaches to the world; where the serious attitude routinely avoids or explains away paradox, inconsistency, and ambiguity, humor embraces them.

However, both the serious and humorous discourse modes are social achievements, not unilateral ones. Whenever someone initiates a performance of a humorous genre, whether it is a canned joke, a practical joke, a cartoon, or simply a joking statement, the performer is attempting unilaterally to switch all interlocutors from the serious to the humorous mode of discourse. Humorous discourse, like all discourse, is interactive-it depends upon the joint construction of all participants, both performers and audiences. Thus, the joker's unilateral switch into humor cannot stand alone; it represents an invitation to others - the joker's intended audiences-to join him or her in the humorous realm, and this invitation demands an immediate response.

It is conventionally said that laughter is the normal and desirable reply to a joke performance. With laughter, the audience signals acceptance of the joker's invitation to join him or her in the humorous mode of discourse for the time being. However, laughter is just one of a variety of avenues open to the humor audience for showing their support of a humorous performance; the same message may be communicated with smiles, with verbal affirmations, and so forth. In addition, the audience can reply to a joke by making further jokes, thus not only affirming but extending the 
foray into the humorous mode. Not infrequently, the positive response to a joke will combine elements of all the above, rendering "humor support" a more accurate term than the conventional "laughter" (Hay 2001). ${ }^{6}$ The audience is expected to recognize and understand the joker's intention to be funny, but they are not obliged to appreciate or agree with it (Hay 2001). Thus, the possibility of humor support implies the possibility of its opposite, unlaughter-when audiences withhold appreciation or agreement and reject the invitation to joke.

\section{"Tom Cruise All Wet": Laughter is Immoral, But Unlaughter is Ridiculous}

Practical jokes frequently give rise to unlaughter, especially from their victims, because they violate everyday expectations of politeness and ask victims to laugh at their own discomfiture. Thus, they occasion debates that can offer scholars new insights into the popular rhetoric of controversial humor and popular notions about the significance of both laughter and unlaughter. We may begin with a close look at a practical joke that took place in the public arena, one in which the victim's answer to the question "Is this joke OK?" was a resounding "No!" Our example comes from an entertainment news Web site:

It was all supposed to be a joke. A fake reporter and his fake camera crew interviewed actor Tom Cruise at the London premiere of his new film "War of the Worlds." In reality, the group was from a British comedy television show. After asking Cruise a question, the reporter's fake microphone squirted the actor in the face with water.

Cruise was anything but amused. "I'm here giving you an interview and answering your questions and you do something really nasty. You're a jerk," the actor yelled at the "reporter" ....

Eventually, British police arrested the fake reporter and his three-man "camera crew." They may all be charged with assault. (Kurtzberg 2005)

The fake microphone that suddenly squirted water represented a sudden and unannounced change in participants' ideas about what was going on in the interaction, switching the event from a serious interview with a celebrity actor to a humorous practical joke with the same celebrity as its target. The camera crew brought about a unilateral switch from the serious to the humorous mode of discourse, from a bona fide realm in which microphones, cameras, and reporters are what they appear to be to a non-bona fide arena where nothing can be counted upon to be what it seems. The role of the joke's audience, having recognized that the foregoing events were meant to be a joke, was to either support or critique this move into the humorous mode.

Since this practical joke took place in a public arena and was recorded, there was more than a single humor audience involved. These audiences included those who were aware of the planned fabrication before the fact and colluded with the tricksters; the target of the joke; and finally everyone who either saw video recordings or read journalistic accounts of the event after the fact. Since this joke took place during a public media event, it was captured on video, and the recording was soon widely 
available on the Internet and endlessly replayed on newscasts (e.g., Kurtzberg 2005). "It was the squirt heard 'round the world," as one reporter put it: "the squirting footage was played, replayed, slowed down for analysis and dissected like the Zapruder Kennedy assassination film over the following days" (Giammarco 2005). Each of these media outlets created yet more audiences for the fake microphone joke, each of which also took a position either supporting or critiquing the humor performance. I will examine the responses of these audiences in turn.

The tricksters in this case were a reporter and cameraman from a reality television show called Grand Classics, appearing on London's Channel 4. The show regularly plays practical jokes on celebrities and members of the public, filming the results for later broadcast in the style of contemporary reality television shows pioneered by Allen Funt's Candid Camera in the 1940s. Presumably, the show's writers and producers had approved this trick before the pranksters arrived at the scene, forming an audience who were in on the joke from the start. Similarly, since the plan had been to broadcast a recording of the joke, the television audience would have colluded with the show's producers after the fact, being advised in advance that a fabrication was going to transpire and usually also informed of who was being targeted. By definition, anyone who colludes with a practical joke can be said to be offering humor support, and the worldwide popularity of these practical joke shows on both radio and television is testament to that humor support.

In any event, this particular prank never made it to the airwaves because the victim refused to laugh along with the joke. When the victim of a practical joke is let in on the joke, he or she is implicitly being invited to either support or reject the joker's unilateral move into the humorous mode, just as other members of the humor audience are. In the case of televised practical jokes, a precondition of a successful performance is that the target supports the move into the humorous mode after the fact-a positive evaluation that in this context is accompanied by the signing of a release form, which gives the show permission to broadcast the tape. One month prior to the joke played on Tom Cruise, the Grand Classics team played the same joke on another celebrity, Sharon Osbourne. Osbourne responded with a practical joke of her own: she chased down the tricksters and soaked them with a champagne bucket full of water. Her response allowed her to turn the tables on the tricksters, but it did so by extending and building upon the humorous mode - answering a practical joke with another joke and, by so doing, implicitly conveying humor support.

If we think of an audience as those who simply listen to a narrated event or who critique a live or recorded performance from the safety and comfort of their seats, it may seem peculiar to call the victim of a practical joke a part of the joke's audience. The victims of practical jokes enjoy no such distance or safety. On the contrary, they have been publicly fooled and are frequently subjected to varying kinds of physical discomfort-all of which have taken place without their permission. Nevertheless, whenever practical joke victims are let in on the joke, like it or not they join the humor audience, and as such, a response is demanded of them. This demand puts them in a difficult position, because until very recently they themselves were characters in the joke that they are now being asked to judge. Instead of laughing at the antics of stock joke characters like kangaroos in bars or elephants in cherry trees, they are being in- 
vited to laugh at themselves. Since some degree of emotional distance is a prerequisite for being able to see the humor in a situation (e.g., Morreall 1983:103-7), it is not surprising that the victims of practical jokes often respond with unlaughter.

It is a stroke of luck for the ethnographer of humor that a video of the Tom Cruise prank and its aftermath is widely available on the Internet ("Tom Cruise Gets Squirted" 2005). Watching closely, we see that the actor's immediate reaction was a chuckle-but one that he cuts short. In the language of humor theory, relief prompted this initial reaction. Cruise had been surprised by the sudden and unexpected assault with an unknown liquid, but relief followed at once with the realization that no harm had been done. Jennifer Hay argues that there are four stages of humor response: recognition, understanding, appreciation, and agreement (2001). Cruise's brief chuckle represents the first stage, where the target realizes that he has just been the victim of a practical joke, thus recognizing that his interlocutor has shifted into the humorous discourse mode.

However, recognizing an attempted joke is only the first stage of humor response. Next, the audience-in this case, the target - is expected to signal whether or not they agree with the attitudes and sentiments expressed in the joke (Hay 2001). On reflection, Cruise evidently decided that he did not agree with the joke to which he had just been subjected. Instead of laughing or retaliating in the humorous mode, he chose to confront his tormentor. A transcript of the video, which the CBS Early Show rebroadcast the next morning (June 25), gives a detailed view of Cruise's unlaughing response:

MR. TOM CRUise (Actor): Come here. Come here. Why would you do that? Why would do you that?

UNIDENTIFIED woman: That wasn't very funny. That wasn't very funny. Could you please...

MR. CRUISE: No, no, no. It's OK. No, wait one second. What's so funny about that? That's ridiculous. Do you like making less of people? Is that it? Is that-you like doing mean things to people? That's really—hey, hey, no, no, no. Don't run away. Don't run away. That's incredibly rude. I'm here giving you an interview and answering your question and you do something really nasty. You're a jerk. You're a jerk. (Smith and Roth 2005)

The CBS Early Show's official transcript of the video elides several pauses in Cruise's speech and omits the largely inaudible replies that his interlocutor made. Reading the transcript alone, one gets the impression of an enraged tirade, whereas in fact the actor was calm and controlled throughout. As he addressed the fake reporter, Cruise grabbed him by the hand as the man attempted to leave. In doing so, he was restoring the power relations that the joke had briefly upended. A practical joke puts an unflattering spotlight on its target, making that person the unwitting subject of intense audience scrutiny and making him or her an involuntary performer. The joker's place is meant to be behind the scenes, only to be revealed and celebrated after the fact, when a joke has proceeded successfully.

In addition to those who were directly involved in this practical joke, a large number of bystanders observed its unfolding, either at the time or later on television and 
the Internet. Like the immediate audiences, these bystanders, journalists, and members of the media audiences also responded to this attempt at humor, dividing fairly evenly into those who supported the humor and those who agreed with the victim's unlaughter. Several of the latter group noted that the trickster's demeanor was shamefaced. "If the man with the mic didn't feel a bit of a heel, he should have," opined the Aberdeen Evening Express ("Dignified Cruise Is So Cool" 2005). "Based on the moron's reaction," observed a columnist on the Fox News Web site, "he definitely knew that what he did was absolutely wrong. He looked downright embarrassed, as if he knew that from now on he'll forever be that 'jerk' who squirted Tom Cruise with water" (Straka 2005). There was good reason for this embarrassment. Cruise's speech did more than simply say, "That's not funny." He went on to shame the joker, suggesting that his behavior was impolite, mean, and contemptible. Many of the journalists who reported and commented on the event took a similar view, labeling the joke a moronic, puerile, and loutish act, and denying that there was anything humorous about it at all. Frequently, they praised the actor for showing such restraint in dealing with the joker (Beadle 2005; Julius 2005; Straka 2005).

The unlaughter of Tom Cruise and his supporters in the media does not mean they failed to understand the joke. Instead, they were indicating their disapproval of it. Unlaughter is more than the mere absence of laughter; as Billig points out, it is "itself a rhetorical presence, speaking volumes of criticism" (2005:193). An unlaughing response to a joke conveys the sentiment that the joke should not have happened at all and that the laughter of the joker (and those who support him) is inappropriate, even immoral. Unlaughter also makes various claims about the intelligence and character of the would-be joker: in this case, he was called a "jerk," "moron," and "lout" all suggestions that moved smoothly from a critique of the attempted joke to a critique of the person responsible for it.

On the other side of the media chatter about this incident were those who evidently approved of the joke and found fun in the whole affair, adopting a humorous tone themselves. Many of the journalists who took this stance made use of punning headlines that extended the original joke at the expense of the actor: the Sunday Independent headline ran, "Public Tomfoolery Makes Cruise a Joke" (2005), while the Belfast Telegraph ran an opinion piece with the title "A Little Squirt (Or Why Do We All Hate Tom Cruise)” (Gumbel 2005)—this last being a slur on the actor's short stature. Further, many of the Web sites that made the video available labeled the clip with some variation on the joke, such as "Tom Cruise All Wet" (Kurtzberg 2005). By adding jokes of their own, these writers extended the foray into the humorous mode that the original joker had opened with the fake microphone, thus implicitly supporting this move. ${ }^{7}$

If laughter can be immoral, unlaughter can be ridiculous. Cruise, as we have seen, was not amused. For those audiences who supported the joke, his unlaughing response was a focus of attention and became the object of further ridicule and criticism. The common opinion was that, because the squirting was just meant to be a joke, Cruise had overreacted, and many stories implied that he was enraged and out of control, whereas in fact the video shows that he acted with great restraint, albeit with un- 
laughter. Beyond laughing at his minor and temporary discomfiture of being sprayed with water, these writers laughed even more at his alleged loss of composure and his humorless response. In a word, his unlaughter was itself ridiculous.

Unlaughter frequently appears ridiculous - not just in the case of practical jokes, but with all humor. Queen Victoria is infamous for her classic unlaughter response, "We are not amused." As this comment is repeated and parodied, it is almost always with implicit derision of the monarch's inability, unlike normal people, to appreciate a joke. We laugh at her for lacking a sense of humor. Interestingly, the fact that her words were spoken in response to a particular joke-an off-color witticism uttered by a groom-in-waiting (Billig 2005:193) — is almost completely forgotten today. Instead, her words have become emblematic of her entire personality. Similarly, many of those who mocked Tom Cruise's inability to take a joke were motivated by prior animus towards the actor. Whether because of his physical appearance, his personal life, or his affiliation with Scientology, Tom Cruise seems to attract as much antipathy as adoration. For those who were inclined to this negative opinion, the incident in Leicester Square simply supported their a priori belief that he was capable only of "occasional public displays of normality" ("Public Tomfoolery Makes Cruise a Joke" 2005). In other words, his unlaughter was considered to be relevant to the overall assessment of his personality, just as those who supported him saw a connection between the joker's inappropriate attempt at humor and his (the joker's) deficiencies of character.

\section{The Importance of Being Humorous}

The examples of the actor and the queen both suggest that when we talk about the sense of humor, we are talking about much more than a person's proclivity for laughter. Indeed, the sense of humor has achieved far-reaching significance in twentiethcentury Western thought. In his insightful history of the concept, Daniel Wickberg (1998) shows that the notion of a sense of humor did not arise in the Western history of ideas until the mid-nineteenth century. In the last century and a half, however, it has become so thoroughly naturalized and ubiquitous in both academic and lay thinking that it has achieved the status of what Alan Dundes (1971) would call a "folk idea"-that is, a concept that is widespread but usually applied uncritically and is available to everyone as a useful heuristic for making sense of the world, in this case, for talking about and comprehending humor.

Despite its relatively late appearance on the scene, the sense of humor, Wickberg argues, is "the most prominent of personality attributes in the everyday speech of the twentieth century." He goes further: "While we recognize all types of particular 'senses' in describing the qualities of persons, none has become so universally understood and consequently so ossified and stereotyped as the sense of humor" (1998:74). Wickberg describes the process through which, in modern American culture, possession of a sense of humor has become not just a highly desirable characteristic but an essential one. Thus, it is routinely included at or near the top of the list of traits that people seek in a mate. This desideratum is so common in personal ads that they have adopted the 
initialism "soh" to refer to it. Self-help books and popular psychology regularly stress the importance of developing a good sense of humor as part of a well-adjusted personality, and a widespread movement of applied humor specialists has arisen that touts the many positive benefits of a sense of humor (Lewis 2006a).

The contemporary celebration of humor is so strong that those who wish to critique it find themselves very much on the defensive (for example, Billig 2005:8-9; Lewis 2006a; Ludovici 1932:7). Similarly, those who dare to write seriously about humor find themselves obliged to apologize if their books are not funny, and those who choose to object to any particular joke that they find offensive routinely frame their complaint with assertions about their excellent sense of humor (Lockyer and Pickering 2001). In contemporary cultures, these defensive moves are necessary because people are highly motivated to avoid any suggestion that they might lack a sense of humor, a serious charge in today's world. It implies much more than a disinclination to laugh or joke, suggesting that one is "literally an incomplete person" (Wickberg 1998:85), and some even doubt that a human being with no sense of humor could actually exist (88-9). Where a sense of humor is thought to be a sign of emotional and psychological health, the lack of it renders one almost pathologically deficient. "The stereotyped figure of the man without a sense of humor provided an image of the incomplete, the deficient, the lacking, against which could be defined a more appropriate model of personhood," says Wickberg (89). Accordingly, humorlessness has become linked with any number of negative traits such as egotism, fanaticism, superstition, mental inflexibility, and even mental illness. Thus, the critics of Tom Cruise's unlaughter did not hesitate to see it as further proof of what they took to be his abnormal personality.

The modern Western valorization of the sense of humor does not necessarily mean that we modern Westerners laugh and joke more than our ancestors did. What it does mean is that the way we think about humor is inextricably tied to how we think about selfhood. Wickberg argues that contemporary industrialized society is characterized by a particular concept of the self that he calls bureaucratic individualism, the hallmark of which is the "simultaneous affirmation of an ever-deeper interior self-autonomous, natural, and of its own making - and an infinitely adaptable exterior selfsupremely sensitive to social circumstance and the mitigation of conflict" (1998:78). The ancient philosopher said, "Know thyself," but in the contemporary world the equivalent injunction is "Laugh at thyself." To laugh at oneself requires a capacity for self-objectification, the ability to perceive the incongruity between our subjective and objective selves, between our interior estimation of ourselves and the way we appear to others. Thus defined, humor is able to mediate between the paradoxes inherent in the contemporary idea of selfhood and the conflicting demands of psychological versus social modes of being. People with this prized ability to laugh at themselves possess an appropriate sense of proportion and moderation and the ability to adjust to the demands of the bureaucratic order, qualities that make them ideal citizens of modern industrialized society (Wickberg 1998:98-119). Accordingly, it is not surprising that in America today, the sense of humor has become the paragon of virtues. In this cynical age, we do not necessarily expect courage, honesty, industry, or loyalty from others, but a sense of humor is nonnegotiable. 


\section{Unlaughter and Boundary Making}

In small group settings, joking is much more than a pleasantry to pass the time; it is a key component in the regulation of social life, smoothing interactions, serving as a mechanism of social control, and promoting solidarity (Fine and De Soucey 2005). The flip side of solidarity is marking boundaries, which is achieved by emphasizing not only what people inside the group have in common but also the differences that distinguish them from others. More than forty years ago, William Hugh Jansen ([1959] 1965) drew attention to the intergroup characteristics of folklore, and some years later Richard Bauman argued that folklore was involved in constructing social difference as well as solidarity ([1971] 1972). For the most part, however, folklorists studying humor have gravitated toward the solidarity side of the equation. With jokes and other humorous genres, I would suggest, the countervailing forces may be more clearly seen-for example, in ethnic jokes and others that denigrate particular groups. ${ }^{8}$

It is not just the content of jokes that contributes to their exclusionary effect but also the dynamics of differential humor responses. When the butts of these joking put-downs are present, their humor response can have important effects in terms of either inclusion or ostracism. In these situations, the humor response of salient audience members becomes the focus of special attention-reversing the usual state of affairs in performance, where it is the activities of the performer that are scrutinized. Instead, the person who initiates the joke and the joke itself become secondary to the targets' responses, as these are read to gauge suitability for full membership in the group.

Another account of a practical joke, this time from a small group setting, will illustrate the social effects of the target's humor response. The setting is a San Francisco casting agency that had a staff of two men and six women. The women played a simple, traditional practical joke on one of the men, Brian, by tricking him into calling a funeral home and asking for "Myra Mains," which is a pun on "my remains." One of the women describes the joke's aftermath in detail:

BRIAN slams down the phone, angry and upset. He swings his chair around, to where JENNIFER and KATIE are standing and giggling, and says in a loud and bitter voice: "Very funny, guys!"

JENNIFER responds by saying: "It was her idea!"

KATIE laughs uncontrollably, and says, "Myra Mains! Myra Mains! Ha! Ha!” JENNIFER and the two other casting agency workers present continue laughing uncontrollably. By the end of the day, everyone in the office has approached BRIAN and said "Myra Mains, Myra Mains, on line seven for you." BRIAN reacts predictably by pouting all day. (Ladd 1995)

This practical joke is a classic case of divergent humor responses. Brian's sarcastic "very funny" was a formulaic strategy for expressing unlaughter while hopefully also keeping intact his reputation for having a sense of humor. In contrast to the target's unlaughter, everyone else in the office was laughing and replaying or extending the joke. The social consequences of this mix of laughter and unlaughter are clear. 
Practical joke stories typically end with an evaluation of the success or failure of the trick, and this account is no different. The story was recorded at the Folklore Archives at the University of California, Berkeley, by one of the women in the office. Prefacing her evaluation with the observation that "practical jokes are meant to be funny and allow everyone the opportunity to laugh," she echoed an injunction repeatedly found in popular guides to practical joking to the effect that a joke may be considered funny and successful only if the victim can laugh along. By this standard, the Myra Mains joke would seem to be a failure. In this case, however, we are told by the collector that "no one felt uncomfortable when Brian became upset and pouty, because they don't like him." Brian's women coworkers "considered Brian a sexist pig who is nosy, bossy, and condescending." They thought he was egotistical, shunned teamwork, and inappropriately tried to dominate the women in the office, even though he was younger than they were and had only worked there for around three months. According to the collector, the humiliation wrought by the joke was meant to show him that he was not well liked by the others in the office. The jokers were not dismayed by their victim's unlaughter, because the laughter of the rest of the group showed that those who counted - those who were well integrated into the group — supported it. Their shared laughter illustrates the way that humor builds social solidarity, suggesting that everyone possessed the in-group knowledge to get the joke and implying that they had the same attitude toward the object of the laughter. One reason that a move into the humorous mode demands support from others is that such a move is inevitably transgressive, at the very least because it flouts the norms of serious discourse and usually because it breaks everyday norms of politeness and morality as well (Veatch 1998). Thus, joking is always tinged with immorality, and any attempt to either make a joke or support it with laughter requires a temporary suspension of everyday norms and values (Mannell and La Fave 1976). Thus, people who share laughter are coconspirators in playful rule breaking, and such shared transgression, like other shared guilty pleasures, promotes a feeling of solidarity.

Brian's unlaughter only enhanced the solidarity felt by his coworkers because it highlighted the boundary between them and this marginal member. Far from being distressed by his unlaughter, Brian's coworkers mocked it. By describing Brian's response as "pouting," they suggested that it was a childish, immature, and inappropriate reaction. They effectively blamed him not only for being fooled by an old joke but also for his failure to be amused. In short, they were laughing at his unlaughterjust as we saw Tom Cruise's critics laughing at his failure to take a joke. Brian's failure to join in his coworkers' laughter effectively reinforced their prior negative assessment of him. More than adding humorlessness to his other faults (bossiness, sexism, and egotism), his apparent inability to laugh at himself was treated as symptomatic of all those other personality flaws.

Similarly, the social context was the key factor in Brian's evaluation of the joke. When one is the butt of a joke, the question always arises whether the laughter is sympathetic or mocking, inclusive or alienating. The butt must ask, "are they laughing with me or at me?” The joking frame itself provides no ready answer, because humor is always ambiguous, and jokers may choose to hide nefarious purposes behind that ambiguity (Fine and De Soucey 2005; Fry 1968). Accordingly, joke targets must fall 
back on the social context to interpret the communication. Brian, probably suspecting the disdain with which his coworkers regarded him and aware of his low status in the group, had reason to doubt that the jokers' motives were sympathetic ones.

Further, Brian's low status in the group meant that he was less motivated than them to choose the response that smoothed social relations and join in the communal humor support. ${ }^{9}$ Instead, he chose unlaughter, a response that put both him and his tormentors in a bad light. By refusing to countenance the jokers' move into the humorous mode, Brian put his humor competence in doubt. Additionally, his unlaughter suggested that he was unwilling to go along with the transgression inherent in the joke, thus implicitly censuring the joker and her supporters for transgressing in the first place. His unlaughter, therefore, could be read as unflattering to all parties (Billig 2005). This choice only confirmed his coworkers' belief that he was not a team player, because he chose to put his ego ahead of group solidarity and valued his dignity more than smooth social interaction.

Shared laughter enhances solidarity, and accompanying unlaughter from those who are outsiders or marginal only magnifies this effect. Accordingly, in their boundary-setting work, well-integrated individuals sometimes do not wait for chance unlaughter but deliberately provoke it. Marginal group members may become the repeated butts of targeted jokes precisely because they are marginal. The target of the following practical joke, a man named Hafler, worked in a shop repairing electric motors for a medium-sized industrial firm with thirty-three workers. This man's general incompetence made him the frequent target of practical jokes played by the others, although he never took jokes well:

During the afternoon coffee break John, the reconditioning foreman, takes an armature from the scrap bin and exchanges it for the one on Hafler's bench. On returning to his work Hafler attempts to get the slightly larger armature into the stator on his bench to no avail. Most of the men in the shop seem to be tipped off because almost all of them are watching. Hafler jams, pushes, and swears out loud a great deal. The whole shop starts to be filled with laughter. Hafler continues to try for three full minutes. Laughter and comments on his ineffectualness continue all this time, led by Warwick. Finally John takes the right armature from behind Hafler and gives it to him. The shop continues to be filled with laughter. Hafler fits the correct armature in and then goes to the lavatory. (Lundberg 1969:27)

Since Hafler had been the target of practical jokes before, his coworkers were probably not surprised at his response to this one. From past experience, they could count on precisely this reaction. Hafler's strategy for responding usually took the form of pretending that he had not heard the derogatory jokes clearly made in earshot and at his expense; since humor demands a response, his silence would have been read as unlaughter. In the aftermath of this practical joke, he could not very well pretend that he was unaware of it, but again he attempted to avoid making a response by simply retreating to the lavatory. Privately, Hafler expressed very strong negative sentiments about such incidents (Lundberg 1969:27), but although he refrained from expressing his unlaughter publicly, his failure to join in the group laughter was still read as unlaughter and further ostracized him. 
Small groups act like organisms marshalling antibodies to beat off invaders; targeting undesirable members and effectively treating them as outsiders, they are sometimes able to drive these targets out of the group. Humorous texts - not only practical jokes, but also cartoons, canned jokes, and jocular speech-are often a part of this process. In her ethnography of an American corporation, Rosabeth Kanter found that in predominantly male work groups, men told sexist and sexual jokes more frequently in the presence of women than they did when the women were absent. She argues that this joking was a strategy to heighten group boundaries and to test the female tokens who had entered the group (1977:224-30). The test was to see whether the female minority would adapt to the norms of the male majority (Fine 1987) or respond with unlaughter, which would, according to popular thinking, "prove" their humorlessness and unsuitability for full inclusion.

Clearly, then, some jokes are not meant to be funny to all. That is, some humorous performances are intended to include some people in shared laughter but to exclude others. We find this nonobvious motive in many adolescent pranks, especially those associated with Halloween. These jokes are anonymously played on outgroup members, with the goal of provoking unlaughter from them while the teenage pranksters laugh among themselves (Leary 1979; Opie and Opie 1959:377-92). Similarly, children employ a huge repertoire of traditional practical jokes that target adults and are meant to provoke unlaughter, a practice that Iona and Peter Opie call "adultbaiting" (1959:378). These cases are less invitations to join the joker in the humorous or playful mode than they are taunts that rest upon the assumption that the targeted audience will be unwilling or unable to indulge in the humorous mode, even for a little while. In these cases, the tricksters are neither surprised nor dismayed at the unlaughter of their victims. On the contrary, they deliberately provoke it, and in the aftermath of these targeted jokes, the modern folk idea of the significance of the sense of humor is used to create and mark solidarity for some at the expense of ostracizing others.

One might argue that these various forms of targeted joking and one-sided laughter should be called harassment or bullying, rather than humor. On the contrary, I would argue that these cases constitute both harassment and humor. Today the preferred model of humor is described as "laughing with" someone, not "laughing at" them, but it was not always so; humor was not characteristically associated with sympathy until the nineteenth century (Wickberg 1998:64-8). In other words, humor is often sympathetic, but sympathy is not a defining characteristic of humor, and to say that laughter is usually shared and collaborative is to express a moral position rather than an empirical one.

While by no means all joking performances are meant to be unfunny, targeted and one-sided humor occurs fairly often-perhaps more often than we care to admit. There is no denying that many, perhaps most, humor performances are characterized by polite attempts by both joke tellers and their audiences to avoid unlaughter and the trouble that it brings to the smooth course of social relations; ${ }^{10}$ however, deliberately provoked unlaughter is common enough that we ethnographers should not dismiss it as some sort of pathological deviation from "true" humor. Moreover, no one can say how common this phenomenon is because ethnographers-influenced 
by the contemporary bias toward positive humor-have either not looked for it or have dismissed it when it did occur.

\section{The Muhammad Cartoons as Boundary-Heightening Humor}

To summarize: individuals within groups may actively seek to provoke unlaughter from marginalized members. Further, audience responses to humor, both laughter and unlaughter, are closely watched as indicators of a person's "sense of humor," which has significance far beyond an individual's proclivity to make or laugh at jokes, and is seen as pointing to a person's personality, character, and ability to adjust to group norms. In the folk rhetoric of these occasions, the presence or absence of a sense of humor provides a rationale for either including or ostracizing salient individuals. Returning finally to the Muhammad cartoon controversy, we find that the folk ideas (in Dundes's sense of the term) and social dynamics of humor that operate in small groups work in a similar way on the international stage.

Writing in the New York Times, Flemming Rose, the editor of the Danish newspaper that commissioned the cartoons, claimed that the act of subjecting the Muslim prophet to satire was an act of inclusion, not exclusion:

Those images in no way exceeded the bounds of taste, satire and humor to which I would subject any other Dane, whether the queen, the head of the church or the prime minister. By treating a Muslim figure the same way I would a Christian or Jewish icon, I was sending an important message: You are not strangers, you are here to stay, and we accept you as an integrated part of our life. And we will satirize you, too. It was an act of inclusion, not exclusion; an act of respect and recognition. (Rose 2006a)

This is the same argument used to justify the practical jokes and jocular harassment meted out to newcomers in the workplace: since everyone gets this treatment at some time, in doing the same to you we are merely treating you as one of us. However, as with initiation pranks and other humor tests, the social function of the performance depends on the reaction of the butts. The cartoons could only have been inclusive, as Rose claimed they were meant to be, if the target audience of Danish Muslims supported the humor performance, turning the unilateral laughter of the cartoonists and publishers into shared laughter. Instead, even before the controversy hit the world stage, this audience registered their surprise and indignation at what seemed to them to be insensitive provocation.

Responses to humor are colored by the power relations between the joker and the audience-for example, subordinates laugh at the jokes of superiors more often than the reverse (Coser 1960). Since the humor frame cloaks jokers' motives with ambiguity, joke targets interpret jokers' motives and modulate their humor response based on their reading of the social context, including their relationship with the jokers and the way power is distributed between them.

Similarly, the reception of the cartoons did not take place in a vacuum. Muslim responses to the cartoons were informed not only by theology and folk ideas about humor but also by global, regional, and local political contexts, including the status 
of Middle Eastern Muslims as a visible minority in Denmark and the global context of the "war on terror." A demonstrator on the streets of Cairo explained that although the cartoons were "a tiny issue compared to the other issues we are facing in the region like the US aggression in Iraq, this is something people feel they can do something about.... It's a way of venting their anger" (Khalaf and Wallis 2006). Moreover, the protests took place in a wide range of countries, each with its own history and politics. The comments of the Danish Muslim leaders who took the cartoon portfolio to Egypt show that they felt like an embattled minority in the European context (Spiegel 2006), a context that would militate against accepting Rose's inclusive claims at face value. In Egypt and Saudi Arabia, by contrast, governments may have fomented anti-cartoon demonstrations as a way to ease domestic tensions between religious extremists and moderates, and show themselves as defenders of the faith (Rynning and Schmidt 2006).

The built-in ambiguity of the humor frame sometimes covers nefarious uses of jocular harassment. When targeted joking is designed to provoke the unlaughter that alienates, blame for the situation is placed squarely on the targets' alleged lack of humor. We cannot easily dismiss Rose's claim that he meant the cartoons to be inclusive, with the implication that he was surprised by the unlaughter they aroused. However, it is much more likely that unlaughter was being provoked deliberately when newspapers around the world chose to republish these cartoons. Since the backlash had already started, these editors knew what the likely response would be. The editor of the local paper where I was living in Wellington, New Zealand, defended his decision to reprint the cartoons as a "test of tolerance" (Chalpat 2005). That is, he meant to be provocative, and other editors who made the same choice shared this motive. ${ }^{11}$ The object of publishing the cartoons was not just to communicate political satire but also to test the reaction of the target audience. Certainly, when an Iranian newspaper replied by instituting a contest for cartoons about the Holocaust (Harding 2006), this move was a retaliatory act of provocation and boundary heightening, and the outraged responses that the resulting cartoons attracted were only what the Iranian editors had predicted.

The international public debate over the cartoons replicated the dynamics of unlaughter and the social construction of humor found in other controversial humor performances. Weighing in on the controversy, many newspaper readers insisted that they had a right to see the offending images and judge for themselves whether or not they were offensive or amusing. This demand rested upon an aspect of the folk ideas about humor, according to which the sense of humor works as a detector of humorousness and that humorousness is an objective quality inherent in texts. Implicitly claiming to be well-rounded, well-adjusted individuals with a healthy sense of humor, which hardly anyone in modern Western society will admit to lacking, they offered their humor response as a litmus text to resolve the controversy, as if the cartoons could be considered humorous if and only if they found them amusing.

Curiously, some editorials in the English-language press that condemned the cartoons as offensive also added, almost as an afterthought, the charge that the images in question were "not even remotely funny" (Eagle 2006). "Cartoons are meant to be funny," opined another journalist, "but what is most noticeable about the Danish 
caricatures of Muhammad - and the revenge drawings they have spawned-is their distinct lack of humor" (Harding 2006). The implication is that the cartoons would have been more defensible if they had at least been amusing. In fact, the reverse obtains: the cartoons would have been amusing if and only if they were considered defensible and inoffensive- that is, if the person making the judgment were able to adopt the humorous attitude toward the topic. By stating that the cartoons were not even the least bit funny, the writers sought to distance themselves from any suggestion that they approved of the offensive attitudes that the images allegedly contained. This move communicated clear-cut unlaughter; by refusing to support the humor, the writers underlined its transgressive elements and censured the humorists for being at best disrespectful (al-Jadda 2006) and at worst bullying ("Can't Take a Joke" 2006).

While critics saw the cartoons as reflecting poorly on their authors' politeness and ethical sense, as well as their sense of humor, supporters of the cartoons similarly interpreted the protestors' unlaughter as a sign of their psychological makeup. Some people simply saw the problem as the Muslims' lack of humor-like the reader of the Wellington Dominion Post who said in a letter to the editor, "I would suggest that the followers of Islam should get a sense of humour, please" ("Mohammed Cartoons" 2006). For others, this alleged humorlessness - which was taken as proven by the response to this single instance of humor performance-meant much more than an inability to see the funny side of life. For example, in an interview conducted on the eve of the annual meeting of the International Society for Humor Studies in Copenhagen, humor scholar Don Nilson linked the protestors' poor sense of humor to such characteristics as poor education, immaturity, and mental rigidity. He went further, suggesting that religions in general and fundamentalist ones in particular are antithetical to humor and, by implication, betray the same immature, uneducated, undemocratic traits (quoted in Lindskov 2006). ${ }^{12}$

In the cartoon controversy, sense of humor became an indicator of the personality failings not of an individual but of entire nations conceived of as unitary civilizations. "The ability to laugh at oneself, or to shrug off insult, is a sign of both a mature ego and a mature society," argued a writer in USA Today, speaking of the legacy of political humor and satire in the West. "Unfortunately," she went on, "much of the Arab/Muslim world has no such legacy" (Parker 2006). ${ }^{13}$ Similar claims about the humorlessness of the Muslim world, in contrast to the healthy sense of humor found in America, were heard in the aftermath of the September 11 terrorist attacks. Journalist Malcolm Kushner, writing in USA Today, observed:

The current conflict has been characterized as good vs. evil; right vs. wrong; freedom lovers vs. freedom haters; and the list goes on. But [there's] another way of looking at it: the humorous vs. the humorless. Just think about it. The freedom to laugh at each other and ourselves encompasses most of the other freedoms that we cherish so dearly....

America is the country that gave the world the one-liner, the light-bulb joke and the top 10 list.... What have our enemies offered in the way of humor? The answer is found in another indigenous American joke form, the list of the world's shortest books. It must certainly include The Wit and Wisdom of Fundamentalist Islamic Extremists. (Kushner 2001) 
Just as Kushner linked a sense of humor to freedom of speech (and, implicitly, to all that is good, right, democratic, and free), so the enflamed rhetoric of the cartoon debate contrasted Western and Arab/Muslim (the two were frequently conflated) civilizations on the axis of sense of humor.

These broad claims for the value of humor threaten to conflate it with all that is good, right, and noble - a peculiarly elevated position for the average light bulb joke. This situation has come about because of the role that the concept of sense of humor plays in the contemporary Western definition of personhood-a concept that Wickberg argues "holds the paradoxical valuation of both objectivity and subjectivity in place" (1998:5). That is, individuality is valued simultaneously with respect for solidarity and group norms, and the sense of humor-especially a talent for laughing at oneself and at other things one holds dear-is a sign of the ability to mediate these paradoxical demands. By the same token, unlaughter may be read as failure to adjust to group norms, as an overvaluation of the demands of subjectivity over those of objectivity. Thus, Flemming Rose's ex post facto explanation for his decision contained some reactionary complaints about how Muslims and other minorities living in Europe refused to assimilate to Western cultural norms (2006a). In other words, his complaint was that these foreigners refused to fit in, that they valued their own selfhood ahead of the demands of the group and had no sense of proportion-precisely those traits that modern thinking attributes to those who lack a sense of humor.

\section{Conclusion}

Knowledge of the interactional dynamics of humor performance contradicts easy assumptions about humor bringing people together. As Paul Lewis put it in his analysis of the cartoon controversy, "Humor brings people together except when it tears them apart" (2006b). In reality, only shared humor-humor that meets with support from all audience members - contributes to social solidarity. When jokes are aimed at outsiders or marginal group members, shared laughter is not always expected; instead, the unlaughter of these salient individuals, contrasted with the shared laughter of the rest of the group, heightens group boundaries by mocking and ostracizing the outsiders.

Unlaughter is ridiculous to those that do not share it. Furthermore, Western folk ideas about the sense of humor label unlaughter as a sign of serious deficiencies in personality and a symptom of inability to adjust to group norms. In the cartoon controversy, this line of argument was extended to include the character of entire nations. The unlaughter became a symptom not merely of a personal flaw but also of an ideological deficiency. In the West, the publication of the cartoons was seen as evidence of Western tolerance, broad-mindedness, and freedom of expression; in contrast, the complaints about the cartoons were seen as censorious, narrow-minded, uneducated, and immature. Above all, the scale of the protests was seen as showing a lack of a proper sense of balance and proportion-qualities that are essential for success in contemporary Western culture and that are thought to be indicated by the ability to laugh at oneself. 
Given the modern American ideas about the sense of humor, it is no surprise that commentators in the Muhammad cartoon controversy did not hesitate to draw such far-reaching inferences from a single instance of unlaughter-first to assumptions about the protestors' lack of humor, thence to their overall character and personality, and finally to alleged fundamental differences between two civilizations. If Wickberg is correct that our contemporary popular valorization of the ability to laugh at oneself is an expression of the bureaucratic individualism that characterizes contemporary Western culture, then this interpretation of the cartoon protestors was almost inevitable. Things could have gone differently, of course. The cartoons could have led to engagement and dialogue-and they did in some cases. By and large, however, the cartoon defenders misunderstood the depths of Muslim rage, and the protestors seem to have been equally ignorant about the significance of humor and unlaughter in the West. Having unpacked some of the meaning that attaches to Western folk ideas about humor, we may have a better understanding of how some cartoons could have touched off such a worldwide firestorm. If nothing else, the controversy does lead to some discussion about the difficulties of communication in a multicultural world.

\section{Notes}

An earlier version of this research was delivered at the 2006 annual meeting of the International Society for Humor Research in Copenhagen. I am grateful to the scholars at the meeting, to the anonymous reviewers, and also to Abdullahi Ibrahim, Paul Jackson, and John Wolford for their thoughtful comments and responses; I am also thankful for the support of the Indiana University Librarians Association and the Indiana University Office of International Programs.

1. A timeline of the entire sequence of events may be found in Hamilton (2006).

2. The issue was seen as a divide not between Christianity and Islam but between a West seen as overwhelmingly secular and an East viewed as dominated by religiosity.

3. The full quotation reads, "In Denmark, we do have a tradition of satire and humour. We make fun of the Royal Family. We make fun of Jesus Christ... . By publishing these cartoons, we are saying to the Muslim community in Denmark: we treat you as we treat everybody else" ("Danish Editor Defends Mohammed Cartoons to BBC" 2006).

4. Muslim denominations vary in their attitude to aniconism. For fundamentalist Sunnis, the prohibition against depicting the human form is absolute, but for liberal Muslims it is not considered binding. Islamic art past and present is full of depictions of people and other living things, including the Prophet.

5. Modern jokes lend themselves well to text-centered studies because they are ubiquitous and easy to collect. Perhaps more than any other genre of verbal art, jokes are readily subject to the process that Bauman and Briggs (1990) call decontextualization, a process that was helped along considerably by the commodification of the joke from the 1860s onward (Wickberg 1998).

6. Humor scholars sometimes use the term "humorous response" to designate much the same thing, but I find Hay's phrase "humor support" a more felicitous expression of the concept, stressing as it does the social and interactional nature of humorous performance.

7. This method of assenting to the humorous mode by the technique of extension creates joke-telling sessions in which one joke leads to another and yet another. William Fry called these sessions "humor orgies," stressing their competitive nature (1968:106-9). The same competitive spirit is at work in practical joke sequences in which people trade places as the butt and the trickster.

8. Speaking from an evolutionary perspective, R. D. Alexander (1986) argues that humor is invariably some form of direct or indirect ostracism because it always denigrates one butt or another. While his 
theory may be overly reductionist, and while the argument over whether or not humor is inevitably denigratory continues unabated (see, for example, Davies 1998 versus Gruner 1978), most humor scholars would agree that some humor has an exclusionary effect, at least some of the time.

9. Although lay humor theory and some academic theories as well assert that laughter is a spontaneous and uncontrollable reaction to a joking performance (see discussion in Mulkay 1988:93-107), audience responses to humor are controllable, and they are often influenced by the knowledge that laughter or unlaughter will be read as telling indicators of personality and character.

10. As Neal R. Norrick observes, when performing jokes to friends, jokers make every effort to ensure that their audience will laugh (1993:107).

11. Editors may also have been motivated by the desire to sell more papers and by brinkmanship. That is, they wished to avoid the appearance of compromising their allegiance to the principles of freedom of the press by bowing to unreasonable demands. For an analysis of the way journalists used their coverage of the controversy to restate core values of their profession, as well as core cultural values, see Berkowitz and Eko (2007).

12. Psychological research does suggest that there is a negative association between religiosity and sense of humor (Saroglou 2002), and there has been considerable research on the correlation between sense of humor and other adaptive mental traits such as creativity and open-mindedness. However, no psychologist would draw the implications that popular writers and ordinary citizens did about the personality of an individual, let alone an entire religious culture, on the basis of a single instance of unlaughter.

13. On the other side of the debate, one anonymous writer in Maclean's responded by describing the rich tradition of jokes, satire, and wordplay in Arabic culture, both past and present ("It's Not That They Can't Take a Joke” 2006). See also Mir (1991) on humor in the Qur'an and Hayrapetian (1983) for an account of political jokes told by Iranian émigrés, including jokes featuring both God and his Prophet as protagonists. A study of humor in early Islam by Franz Rosenthal found that "the otherworldliness of Islam did little to stop the actual enjoyment and literary appreciation of humor. With all his seriousness and the foreboding doom, the Prophet Muhammad himself possessed much cheerful humanity, and his followers through the centuries have always preserved a good-natured love of jokes and pranks" (Rosenthal 1956; quoted in Mir 1991:181). However, all of these attempts to defend Islam by pointing out that Muslims have a sense of humor buy into the same assumptions about the nature and value of this "sense" that their opponents hold.

\section{References Cited}

Alexander, R. D. 1986. Ostracism and Indirect Reciprocity: The Reproductive Significance of Humor. Ethology and Sociobiology 7(3-4):253-70.

Attardo, Salvatore. 2001. Humorous Texts: A Semantic and Pragmatic Analysis. Humor Research, no. 6.

New York: de Gruyter. 2003. Introduction: The Pragmatics of Humor. Journal of Pragmatics 35(9):1287-94.

Barrick, Mac E. 1970. Racial Riddles and the Polack Joke. Keystone Folklore Quarterly 15(1):3-15.

Bauman, Richard. [1971] 1972. Differential Identity and the Social Base of Folklore. In Toward New Perspectives in Folklore, ed. Américo Paredes and Richard Bauman, pp. 31-41. Austin: University of Texas Press.

1986. Story, Performance, and Event: Contextual Studies of Oral Narrative. New York: Cambridge University Press.

Bauman, Richard, and Charles L. Briggs. 1990. Poetics and Performance as Critical Perspectives on Language and Social Life. Annual Review of Anthropology 19:59-88.

Beadle, Jeremy. 2005. Attack on Tom Was Moronic ... Just Like Happy Slapping. The Mirror [Great Britain], June 21, 2005.

Ben-Amos, Dan. 1972. The Elusive Audience of Benin Narrators. Journal of the Folklore Institute 9(2/3):17784. 
Bendix, Regina. 1984. Playing the Joker: Personal Biography and Attitudes in the Study of Joke Performance. Folklore Forum 17(1/2):209-19.

Berkowitz, Dan, and Lyombe Eko. 2007. Blasphemy as Sacred Rite/Right: "The Mohammed Cartoon Affair" and Maintenance of Journalistic Ideology. Journalism Studies 8 (5):779-97.

Billig, Michael. 2005. Laughter and Ridicule: Towards a Social Critique of Humour. London: Sage.

Bronner, Simon J. 1984. "Let Me Tell It My Way": Joke Telling by a Father and Son. Western Folklore 43(1):18-36.

. 1985. What's Grosser Than Gross? New Sick Joke Cycles. Midwestern Journal of Language and Folklore 11(1):39-49.

Brunvand, Jan H. 1970. Some Thoughts on the Ethnic Regional Riddle Jokes. Indiana Folklore 3(1):12842.

“Can't Take a Joke” Is the Age-Old Taunt of the Bully. 2006. Independent on Sunday [Great Britain], February 5, 2006.

Carrell, Amy. 1997. Joke Competence and Humor Competence. Humor 10(2):173-85.

Chalpat, Sonti. 2006. Cartoons “Test of Islamic Tolerance.” Dominion Post [New Zealand], February 4, 2006.

Coser, Rose Laub. 1960. Laughter among Colleagues: A Study of the Social Functions of Humor among the Staff of a Mental Hospital. Psychiatry 23:81-95.

Danish Editor Defends Mohammed Cartoons to BBC. 2006. Agence France Press, February 3, 2006.

Davies, Christie. 1998. Jokes and Their Relation to Society. New York: Mouton de Gruyter.

Dignified Cruise Is So Cool. 2005. Aberdeen Evening Express [Great Britain], June 23, 2005.

Dundes, Alan. 1971. Folk Ideas as Units of Worldview. Journal of American Folklore 84(331):93-103. . 1987. Cracking Jokes: Studies of Sick Humor Cycles. Berkeley, CA: Ten Speed Press.

Eagle, James. 2006. Disrespecting the Prophet? The Morning Star [Great Britain], February 11, 2006.

Ellis, Bill. 1991. The Last Thing ... Said: The Challenger Disaster Jokes and Closure. International Folklore Review 8:110-24.

Fine, Gary Alan. 1984. Humorous Interaction and the Social Construction of Meaning: Making Sense in a Jocular Vein. Studies in Symbolic Interaction 5:83-101.

-1987. One of the Boys: Women in Male-Dominated Settings. In Changing Men: New Directions in Research on Men and Masculinity, ed. M. S. Kimmel, pp. 131-47. Newbury Park, CA: Sage.

Fine, Gary Alan, and Michaela De Soucey. 2005. Joking Cultures: Humor Themes as Social Regulation in Group Life. Humor 18(1):1-22.

Fry, William F. 1968. Sweet Madness: A Study of Humor. Palo Alto, CA: Pacific Books.

Giammarco, David. 2005. My Jet-Lagged Cruise with Tom. The Globe and Mail [Canada], June 28, 2005.

Glassie, Henry H. 2006. The Stars of Ballymenone. Bloomington: Indiana University Press.

Gruner, Charles R. 1978. Understanding Laughter: The Workings of Wit and Humor. Chicago: NelsonHall.

Gumbel, Andrew. 2005. A Little Squirt (Or: Why Do We All Hate Tom Cruise?). Belfast Telegraph, June $21,2005$.

Hamilton, Marci A. 2006. World Must Stand up to Religious Censors. USA Today, March 6, 2006.

Harding, Gareth. 2006. Tit-for-Tat in Cartoon Spat. UPI, February 7, 2006.

Hay, Jennifer. 2001. The Pragmatics of Humor Support. Humor 14(1):55-82.

Hayrapetian, Juliet Rad. 1983. Political Humor: Its Function and Significance in the Iranian Revolution. Folklore and Mythology Studies 7:24-39.

It's Not That They Can't Take a Joke. 2006. Maclean's, 20 February, 2.

al-Jadda, Souheila. 2006. Faith, Free Speech: Where to Draw the Line? USA Today, February 8, 2006.

Jansen, William Hugh. [1959] 1965. The Esoteric-Exoteric Factor in Folklore. In The Study of Folklore, ed. Alan Dundes, pp. 43-56. Englewood Cliffs, NJ: Prentice-Hall.

Johnson, Robbie Davis. 1973. Folklore and Women: A Social Interactional Analysis of the Folklore of a Texas Madam. Journal of American Folklore 86(341):211-24.

Julius, Marshall. 2005. The Prank Outsiders Taking Us to a New Low in Drivel. Sunday Express [Great Britain], August 21, 2005. 
Kanter, Rosabeth Moss. 1977. Men and Women of the Corporation. New York: Basic Books.

Khalaf, Roula, and William Wallis. 2006. Anti-Prophet Cartoons "Will Play into Extremist Hands." Financial Times [Great Britain], February 3, 2006.

Kirshenblatt-Gimblett, Barbara. 1975. A Parable in Context: A Social Interactional Analysis of a Storytelling Performance. In Folklore: Performance and Communication, ed. Dan Ben-Amos and Kenneth S. Goldstein, pp. 105-30. The Hague, Netherlands: Mouton.

Kurtzberg, Brad. 2005. Tom Cruise All Wet after Fake Reporter Squirts Him with Water. http://www .elitestv.com/pub/2005/Jun/EEN42b7170973574.html, accessed November 23, 2007.

Kushner, Malcolm. 2001. Unleash the USA's Secret Weapon: Humor. USA Today, October 4, 2001.

Ladd, Mary Ruth. 1995. Myra Mains. Folklore Archives. University of California, Berkeley.

Leary, James P. 1979. Adolescent Pranks in Bloomington, Indiana. Indiana Folklore 12(1):55-64.

Lewis, Paul. 2006a. Cracking Up: American Humor in a Time of Conflict. Chicago: University of Chicago Press.

- 2006b. Islamic Rage: Sometimes, It Hurts to Laugh. Hartford [Connecticut] Courant, February 6, 2006.

Lindskov, Anders. 2006. The Prophet and Double Vision. DPU Quarterly Newsletter. http://www.dpu.dk/ site.asp? $\mathrm{p}=8649$ \&newsid1 $=4002$, accessed December 23, 2006.

Lockyer, Sharon, and Michael Pickering. 2001. Dear Shit Shovellers: Humour, Censure, and the Discourse of Complaint. Discourse and Society 12(5):633-51.

Ludovici, Anthony M. 1932. The Secret of Laughter. London: Constable.

Lundberg, G. C. 1969. Person-Focused Joking: Pattern and Function. Human Organization 28(1):22-8.

Mannell, Roger, and Lawrence La Fave. 1976. Humor Judgements and the "Playful Attitude." In The Anthropological Study of Play: Problems and Prospects, ed. David F. Lancey and B. Allan Tindall, pp. 230-8. Cornwall, NY: Leisure Press.

Michael, Nancy. 1995. Censure of a Photocopylore Display. Journal of Folklore Research 32(2):137-54.

Mir, Mustansir. 1991. Humor in the Qur'an. The Muslim World 89(3-4):179-93.

Mitchell, Carol A. 1977. The Sexual Perspective in the Appreciation and Interpretation of Jokes. Western Folklore 36(4):303-30.

Mohammed Cartoons: Your Views. 2006. Dominion Post [New Zealand], February 6, 2006.

Morreall, John. 1983.Taking Laughter Seriously. Albany: State University of New York Press.

Mulkay, Michael. 1988. On Humour: Its Nature and Its Place in Modern Society. Oxford: Polity Press.

Norrick, Neal R. 1993. Conversational Joking: Humor in Everyday Talk. Bloomington: Indiana University Press.

Opie, Iona, and Peter Opie. 1959. The Lore and Language of Schoolchildren. London: Oxford University Press.

Oring, Elliott. 1992. Jokes and Their Relations. Lexington: University Press of Kentucky.

- 1995. Arbiters of Taste: An Afterword. Journal of Folklore Research 32(2):165-74. 2003. Engaging Humor. Urbana: University of Illinois Press.

Parker, Kathleen. 2006. Faith, Free Speech: Where to Draw the Line? USA Today, February 8, 2006.

Public Tomfoolery Makes Cruise a Joke. 2005. Sunday Independent [Ireland], June 26, 2005.

Raskin, Victor. 1985. Semantic Mechanisms of Humor. Boston: D. Reidel.

Rose, Flemming. 2006a. Why I Published the Muhammad Cartoons. New York Times, May 31, 2006. . 2006b. Why I Published Those Cartoons. Washington Post, February 19, 2006.

Rosenthal, Franz. 1956. Humor in Early Islam. Leiden, Germany: E. J. Brill.

Rynning, Sten, and Camilla Holmgaard Schmidt. 2006. Muhammad Cartoons in Denmark: From Freedom of Speech to Denmark's Biggest International Crisis since 1945. UNSCI Discussion Papers 11:11-21.

Saltzman, Rachelle, and Moira Smith. 1995. Introduction to Tastelessness. Journal of Folklore Research 32(2):85-99.

Saroglou, Vassilis. 2002. Religion and Sense of Humor: An A Priori Incompatibility? Theoretical Considerations from a Psychological Perspective. Humor 15(2):191-214.

Slackman, Michael, and Hassan M. Fattah. 2006. Muslim Who Ran Cartoons Paying the Price; Efforts at Dialogue Get Overwhelmed. International Herald Tribune, February 23, 2006. 
Smith, Harry, and Richard Roth. 2005. Tom Cruise Gets Squirted in the Face by Pranksters during Interview for "War of the Worlds" Premiere. CBS News Transcripts: The Early Show, June 20.

Smith, Moira. 1995. Whipping up a Storm: The Ethics and Consequences of Joking Around. Journal of Folklore Research 32(2):121-36.

Smyth, Willie. 1986. Challenger Jokes and the Humor of Disaster. Western Folklore 45(4):243-60.

Spiegel. 2006. Alienated Danish Muslims Sought Help from Arabs. Spiegel Online, February 1. http:// www.spiegel.de/international/0,1518,398624,00.html, accessed June 22, 2007.

Spiegelman, Art. 2006. Drawing Blood: Outrageous Cartoons and the Art of Outrage. Harper's Magazine, June, 43-52.

Straka, Mike. 2005. Grrr! Tom Cruise, Meet the Moron, June 20. http://www.foxnews.com/ story/0,2933,160160,00.html, accessed November 23, 2007.

Thomas, Jeannie B. 1997. Dumb Blondes, Dan Quayle, and Hillary Clinton: Gender, Sexuality, and Stupidity in Jokes. Journal of American Folklore 110(437):277-313.

Tom Cruise Gets Squirted. 2005. http://www.ifilm.com/video/2673927, accessed June 20, 2007.

Veatch, Thomas C. 1998. A Theory of Humor. Humor 11(2):161-215.

Walle, Alf H. 1976. Getting Picked Up without Being Put Down: Jokes and the Bar Rush. Journal of the Folklore Institute 13(2):201-17.

Wickberg, Daniel. 1998. The Senses of Humor: Self and Laughter in Modern America. Ithaca, NY: Cornell University Press. 